\title{
SCIENCE
}

NEW YORK, JULY 14, 1893.

\section{THE WRENS OF TRAVIS COUNTY, TEXAS.}

BY CHARLES D. OLDRIGHT, AUSTIN, TEXAS.

1. Catherpes Mexicunus conspersus, Cañon Wren. This bird is an "endewic" species, its occurrence in any district depending on the topographic features. The great rock walls of the Colorado River, and the numerous side cañons form an ideal dwelling-place for this little bird, and here it may be found at all seasons, and its loud, ringing song re-echoes from cliff to cliff in the dreary days of November as well as in April's sunshine. But it penetrates into the city, and every morning this year one of the first sounds that $I$ have heard has been the matutinal song of a cañon wren whose nest was in a cranny of an unoccupied house standing next to mine.

The cañon wren (as active a busy-body as the rest of his tribe) seems to be never too tired to sing. Reclining on the soft grass at the margin of the rivulet you look up the great frowning cliff and see a tiny bird, now clinging to the perpendicular rock, now (issappearing in some crevice of the cliff and then perching on a projecting fragment, he utters a succession of clear bell-like notes in a descending scale.

As this wren usually nests in some crevice far up in the cañon wall its eggs are of:en safe from the hands of the oölogist. Many times have I gazed longingly at a few straws projecting from a hole, while the owner of the nest watched me complacently. In such cases " 'tis distance lends enchantment to the view." Howerer, I have had the pleasure of examining several nests containing eggs and soung, and as I have never seen any detailed account of the nidefication of this species, I will give some particulars about them.

This bird begins building early in the season, a nest with hatching eggs in it having been taken on the 30th day of March. In 1890 fresh eggs were found April 3, 4 and 11.

The nest is placed in some cranny or hole of conrenient size, always in the face of the cliff; other situations are on a rafter in a barn, under the cornice on a reranda and in the chimney of an uninhabited house.

The nest is composed of grass and weeds and lined warmly with hair, wool and cotton. The complement of eggs varies from three to five, four being perhaps more usual than either of the other numbers.

The eggs always hare a clear white ground, while the markings vary from a very slight sprinkling of brown pin-points to numerous large blotches and spots of reddish-brown and lilac, forming a confluent ring encircling the crown; this is the most common pattern of coloration. Their shape is orate or rounded ovate, but I hare seen one prriform egg in the nest with three cther normally shaped eggs.

2. Phryathorus ludovicianus, Carolina Wren. An abundant bird in the bottom lands along brooks and in all heavily timbered country. The Carolina wren is another fine singer, but spends too inuch of its time in scolding owls, crows and men. But of ten, especially in the spring and at sunset on a summer's day, one of these birds will perch on the topmost twig of a tall shrub and will, with his tail drooping and head thrown back, call "sweet William" until the woods resound. By the way, "sweet William" does not express the exact sound of the bird's notes to me, but I am so hopeless of expressing birds' voices by English words that I will not attempt to amend it.

This bird cannot be called particular in its choice of a nestingplace, for their nests hare been found in hollow logs, under the cornice of a house, in a tin can placed in a tree, in a hole in a rock wall and on the window.sill of a farmbouse. The hollow $\log$ is, I believe, the most usual situation. The nest is made to fit the cranny in which it is built and generally fills it. Twigs, grass weeds, leaves, hair, cotton, wool, rags, paper and even other materials enter into its composition. In shape it is more or less rounded, with an entrance in the side. The eggs are four, fire or six in number, fire being most common.

There is not much variation in the eggs; the markings being in some heavier than in others. The ground color is white, spotted thickly and finely with specks of reddish-salmon color and !lilac, generally forming a poorly defined ring around the crown. The ground color is usually well concealed.

Fresh eggs may be found from April 1 to May 15, the height of the breeding season being during the middle of April.

3. Thryothorus bewickii murinus, Baird's Wren.

Probably our commonest wren, found in all kinds of country, bottoms or uplands, forest or prairies, mounta ins or plains. I beliere, however, that Baird's wren prefers a broken=country, little patches of prairie and mesquite groves alt ernating with the timber.

A number of these birls must spend their whole lives in the city of Austin, for in nearly every garden one may find a pair.

They are fussy little creatures hardly ever silent for a moment but keeping up a lively chatter or queruluus " chee, 'chee, chee." But all through the spring, even as early as January, the males are great singers, and early on an April morning one cannot go far without hearing the sweet and cheerful song of one of these little birds. At such times one finds the bird perched,in a.tree-top, but on other occasions he will be hopping amongst the bushes or along a rail fence, flirting his long tail, uttering a continuous " chirp, chirp," and at each third " chirp" stopping a moment to pour forth his little ditty. This is kept up forjhourstat a time.

In February the wrens become restless and may be seen promenading the back yards in pairs, peering into every hole and bird-box. They seem to be often undecided as to alnesting place, for I have known of a pair starting four diffe rent nests witlin a week, without any apparent cause for their fickleness. Any place seems good enough for this bird to start a nest-though as I have just stated they are more particular about its final location. Many people here have put small wooden boxes at their gates for the reception of mail matter, and I verily believe that each one is looked into once a year by a Baird's w ren, with a view to building in it, and indeed many are chosen as nesting sites.

The nest is simply a mass of rubbish-but always warmly and softly lined with feathers or cotton. Six is a common complement of eggs, but as many as eight or as few as four may constitute a full set. The eggs are white, more or less speckled with brown of varying shades and lilac, sometimes the specks of reddish brown are thickly and uniformly distributed, again they aie collected into a ring surrounding the crown or else rather larger specks of chocolate brown and lilac shell markings are more sparingly disposed.

Two "albino" eggs came under my notice last spring; one was. immaculate white, the other had a very faint speckling on the crown; both these eggs were with other normally colored eggs. I also found a peculiar "runt" egg of this species, it is of normal coloration but measures only .55 by .44 , being thus the size of a humming bird's egg. I found it one day in a hole in a telephone pole, and left it thinking that more eggs might be laid, as I saw the birds at hand; but when, after the lapse of sereral days, none were deposited, I took it. Why the bird laid no more I do not know. Surprise at the first one may have had something to do with it.

4. Troglodytes aëdon aztecus, Western House Wren.

Of this member of the family I can say but little, for during his winter stay with us he is very silent and indeed shy.

I am aware that he, like his kinsmen, can scold with remarkable vehenence, for I have heard him. While he remains with us he is to be found in the creek bottoms wherever there are 
thickets of brush.wood. He remains with us until late in the spring, indeed the other wrens have young ones before he thinks of leaving for his northern "summering place." Last year I saw some on the 22nd of April. I sent one of them to Washington where the "bird doctors" pronounced it "aztecus."

5 Salpinctes obsoletus, Rock Wren.

This bird hardly deserres a place to itself, being quite uncommon and differing little in appearance and mode of life from the Cañon wren, which seems to represent it with us. It is more common further west. Indeed, this is the most easterly record in Texas of its occurrence.

\section{METALLIC CARBIDES.}

BY F. P. VENABLE, CHAPLE HILL, N. C.

THIs name is given to compounds formed by the direct union of carbon with the metals. They are not numerous nor do they sf em to be easy of formation and it is rery difficult to prepare them in a pure and definite form. Consequently they have been but little studied so far. None of them are known to occur in minerals of terrestrial origin.

Interest in these bodies has been heightened of late $b y$ the discovery of new ones, and by the instructice decompositions of some of them.

First as to the general mode of formation. They are usually formed $\mathrm{b} g$ the action of intense heat upon the metal in the presence of carbon. The form of this carbon is capable of being greatly varied. Graphite, amorphous carbon and many hydrocarbons can be used. The carbide is especially formed when the metal is being extracted from its compounds, that is, in the nascent state. Several metals thus unite with carbon in the process of manufacture, as zinc, copper and notably iron, and the presence of the carbides renders the metal hard and brittle. The purification and analysis of these bodies is not at all an easy problem, and hence little or nothing is known of their formulas or chemical constitution Five or more formulas hare been assigned to iron carbide, and, of course, several may exist, still the correctness of any of these formulas is questionable.

The heat of the ordinary furnace is sufficient to form the carbides of the metals already mentioned. For others, more recently discovered, as the carbides of aluminium, of calcium, of barium, etc., the intense heat of the electric furnace is necessary. The first of these, aluminium carbide, is a most interesting body, of a light golden yellow color, it can be gotten from the electric furnace in a mass of corundum and metallic aluminium. It was described first by Sterry Hunt. Though it will stand intense heat in the air without appreciable change, yet really it is undergoing change all the time as is proved by the odor of hydrocarbons corning from it and the fact that left to itself in air it crumbles in a few weeks into a mass of white alumina. A few shining golden scales of the pure substance can be separated, but so far no analysis has been given to the world.

All of these carbides, under certain conditions, give off their carbon in the form of hydrocarbons. The same smell can be detected in all during their decomposition. In some cases, as iron and zinc, the decomposition is caused by the action of an acid. The carbides of the earths decompose in moist air and more rapidly in water. Calcium carbide decomposes the most energetically of them all. The erolution of the hydrocarbons would be called violent. Of course. the hydrogen needed for the reaction comes from the decomposition of the water or from the hydrogen acid.

A most interesting fact recently published in the scientific journals, is that the calcium carbide on decomposition yields lime and pure acetylen gas. The acetylen seems very pure. A thousand cu. $\mathrm{cm}$. of the evolved gas was passed into an ammoniacal solution of copper chloride, and not a bubble went through. All was absorbed and precipitated. This is very important because the modes of preparing acetylen in common use are tedious or expensire, and hence this important hydrocarbon has not been as carefully studied as it otherwise might bave been.

The formation of $\mathrm{h} s$ drocarbons by the decomposition of iron caibide has furnished a basis for one of the theories as to the origin of petroleum. If great quantities of iron carbide existed beneath the earth's surface and were subjected to decomposing influences, such oils and gases as are found in petroleum regions might rery easily be formed.

So far there has been little utilization of these carbidts commercially. One of the purer furms of iron carbide is used in a prucess for preparing metallic sodium, and the iron carbide in cast iron confers upon it many of its useful properties. If these bodies can bo produced cheaply enough, however, there is strong probability that certain of them will prove very useful.

\section{PHILOSOPHY IN THE COLLEGE CURRICULUM.}

by holmes dysinger, Carthage college, carthage, ill.

STUDIES under the name of philosophy are to be found in almost every college curriculum. Either because the subject is too vague or abstruse for the comprehension of the average student, little more than elementary rsychology, which is rightly regarded as a uecessary part to the introduction to the subject proper, and a brief discussion of practical ethics, are taught in most of the schools outside of the few real universities. While the number of subjects advocated for introduction into the college course is increasing constantly, one so fundamental as philosophy should not be neglected. A part from its theoretical value, it has practical bearings upon the intellectual range of a man, regardless of the system he adopts, that commend it to the thoughtful consideration of educators.

The subject-matter with which philosophy deals bears a peculiar relation to all other subjerts in the course, in as much as its oñice is, partly at least, to systematize and explain all the principles of the particular sciences. This gives the unity so desirable in a course of study, and so essential to the thoroughly-trained mind. From this it serres the highest purpose in education and deserves a prominent place in every course of liberal culture.

The philosophical powers of man are last in order of derelopment. The subject-matter makes ic necessarily so. It is the most abstruse of all forms of knowledge. The mind in its unfolding passes up through perception and conception to the realm of widest generalizations and the discovery of the principles that are assumed in all our thinking. Philosophy deals with forms of knowledge that stand at the farthest remove from that furnished in so-called presentation - the first derelopment in the mind's unfolding.

When the mind reaches that stage of derelopment in which it apprehends the principles fundamental to all knowledge, it turns in upon itself and critically examines its own processes and assumitions to determine the certainty of being and the validity of our ltnowledge. This is the bighest stage in man's intellectual ascent. Here he stops, He has completed the circuit of the globe of knowledge. He started with the facts furnished in sense and consciousness, and ends in the principles that underlie and embrace all knowledge. These stand accredited in his own thinking. Besond this the mind of man cannot penetrate.

That many students cannot attain tlis stage of knowledge is evident to all who have taught the upper classes in our colleges; that but few who attempt it get further than the outer court, is to be expected; but that all are gr: atly benefitted intellectually would not be denied by those who bave looked into the merits of the case and examined the eridence with impartiality. A few additional facts will give our reasons for this conclusion.

Notwithstanding its abstruseness, as a discipline in thinking and in logical method, philosophy has no equal. Facts as furnished by the senses and distinguished from principles are not dealt with in philosophy, but the relation of facts to one another and to all things else. All these in a system of philosophy deserving of study or worth elaboration must be included in their relations of coördination and subordination. The unity of all $b$ ing is the ultimate problem of philosophy. A narrower range and lower ideal may satisfy science, but it cannot attain to that which comprehends all knowledge. Only the mind well disciplined in logical method can grasp the facts, but the one who attempts to do so will develop a porrer that is the possession of few and the desire of all 